Food, Dairy and Home Economic Research

http:/www.journals.zu.edu.eg/journalDisplay.aspx?Journalld=1\&queryType=Master

\title{
UTILIZATION OF OLIVE CAKE BY-PRODUCT FOR IMPROVEMENT OF SHELF LIFE AND QUALITY OF CHICKEN MEAT
}

\author{
Waleed Z. Badawy ${ }^{*}$ and A.A. Saleh ${ }^{2}$ \\ 1. Food Technol. Dept., Fac. Agric., Kaferelsheikh Univ., Egypt \\ 2. Poult. Prod. Dept., Fac. Agric., Kaferelsheikh Univ., Egypt
}

Received: 14/08/2018 ; Accepted: 02/09/2018

\begin{abstract}
Olive oil extraction a remaining cake rich in oil that can be used in chicken diets. The objectives of this study are to determine the chemical composition, minerals and fatty acid composition of olive cake (OC). The effect of addition of OC (2 and 4\%) to chicken diets on the sensory evaluation, oxidative stability (OS) and bacteriological activity of chicken meat during 15 days storage period at $4^{\circ} \mathrm{C}$ were also investigated. The results indicated that, the ether extract and crude fiber contents of OC were 12.57 and $50.87 \%$, respectively. In addition, OC contained high percentage of minerals such as $\mathrm{K}, \mathrm{Mg}, \mathrm{Ca}$ and $\mathrm{P}$. In contrast, analysis of fatty acids using GLC revealed that the unsaturated oleic acid (18:1) was predominant (72.1\%). Moreover, OS of chicken meat fed on $4 \%$ olive cake was significantly higher than that of $2 \%$ olive cake during the storage period (15 days). It can be concluded that OC is considered as a good by-product of nutrients and addition of OC in the chicken diet had an influence on reducing of lipid oxidation and delaying colour and odour deterioration in chicken meat during the storage period.
\end{abstract}

Key words: Olive cake, chicken diet, lipid oxidation, minerals.

\section{INTRODUCTION}

The requirements for energy have always increased because of the human activities, industrialization and population increase (Alhusein et al., 1993).

The intensive developing and processing of olives produces large quantities of by-product approximately $800 \mathrm{~kg}$ olive cake/ton which are used in different ways (Martín-García et al., 2003).

Olive is a main crop in Mediterranean countries, Argentina and Chile. Olive oil plantations coexist with major farmers sheep production systems in Central Chile. Olive oil extraction is related with the manufacture of abundant quantities of residues (olive cake) that are difficult to arrange and may have a negative environmental effect. OC is an agro-industrial by-product that contains of olive skin, pulp, stone and water (Alburquerque et al., 2004).

One of the chief challenges in marketing of meat is the retention of quality during storage and sells display by delaying the oxidative deterioration of muscle constituents, such as cholesterol, fatty acids and which concessions the sensory and dietary quality of meat (Hur et al., 2007; Faustman et al., 2010).

The potential use of $\mathrm{OC}$ as a replacer part of the cereal concentrate in diets for small ruminants has been discovered, as this might partially donate both to solving the problem of the removal of OC and to reduce of production prices for livestock feeding. Although, the work of the effect of OC in minor ruminants diets on feed digestibility and animal performances has been relatively commonplace (Molina-Alcaide and Yáñez Ruiz, 2008).

\footnotetext{
* Corresponding author: Tel. : +201004114701 E-mail address: walid.metwali@agr.kfs.edu.eg
} 
Olive cake, a mixture of skins, pulp, woody endcarp and seeds, is characterized by a great content in phenolic antioxidants, such as tyrosol, hydroxytyrosol and secoiridoids derivatives (Servili et al., 2009).

Several studies testified that OC was added at $2-5 \%$ to broiler diets without contrary effects on development performance, carcass features, inner body organs and blood hematology (Rupic et al., 1999; Abo-Omar, 2005; Zangeneh and Torki, 2011). However, a higher level of OC adversely affects nutrient digestibility (AboOmar, 2000).

The oxidative stability (OS) of meat is dependent on the balance between muscle prooxidant and antioxidant components. Muscle antioxidants include endogenous antioxidant, in addition, molecules of dietary source, like carotenoids, tocopherols (Descalzo and Sancho, 2008).

Lipid oxidation is one of the chief factors controlling the acceptability and quality of meat because it is responsible for the development of several changes in meat, besides, the production of potentially toxic compounds (Zanardi et al., 1998). Furthermore, lipid oxidation is an important matter of concern to retailers because its discolouration effects, plus off-flavour improvement, powerfully affect the meat shelf life (Allen and Cornforth, 2010).

The objectives of current study are to estimate the chemical composition, minerals and fatty acid composition of OC. The influence of addition of OC ( 2 and $4 \%$ ) to chicken diet on the sensory evaluation, the OS and bacteriological activity of chicken meat during the storage period at $4^{\circ} \mathrm{C}$ were investigated for improvement of quality and shelf life of chicken meat by decreasing lipid oxidation and delaying colour and odour deterioration in chicken meat during the storage period.

\section{MATERIALS AND METHODS}

\section{Raw Materials}

The birds (SASSO broiler chicks) and olive cake powder were provided from Al-Sabeel AlGadidah Company for poultry production, Tanta, Gharbia District, Egypt.

\section{Methods}

Proximate chemical composition of olive cake

Moisture, ether extract, protein, crude fiber, ash and crude fiber contents of olive cake were estimated using the methods outlined in AOAC (2005).

\section{Determination of minerals content of olive cake}

Minerals were determined according to Chapman and Pratt (1978). After wet ashing zinc $(\mathrm{Zn})$ and manganese $(\mathrm{Mn})$ were determined using the atomic absorption spectrophotometer (Zeiss FMD3). Calcium $(\mathrm{Ca})$, potassium $(\mathrm{K})$ and sodium $(\mathrm{Na})$ were determined using a flame photometer. Phosphorus (P) was estimated photometrically as the phosphorus molydate complex spectrophotometer at wave length of $650 \mathrm{~nm}$, using a standard curve in relation to the method described in AOAC (2005).

\section{Fatty acids composition of olive cake}

Lipids from OC were removed with chloroform/methanol (2:1, V/V) by Folch et al. (1957) method and methylated with modifications of Sukhija and Palmquist (1988). The gas chromatography (GC) conditions were similar to those mentioned by Vargas-Bello-Pérez et al . (2013).

\section{Preparation of chicken diets}

Ninety birds (SASSO broiler chicks) one day age (according to the nutrition guide of Cobb stern) were distributed into three treatment groups and each group has 3 replicates $(n=10$ birds). The first group was used as control and fed on basil diet (The basil diet was prepared by commercial ingredients as like yellow corn, soybean meal, and corn gluten and the chemical compassion of basil diet and olive cake diets are same and the diets analysis were $21.5 \%$ crude protein, $3050 \mathrm{kcal} / \mathrm{kg}, 1.0 \% \mathrm{Ca}$ and $0.46 \%$ Phosphorus), the second group fed diet contains $2 \%$ olive cake and the third group fed diet contains $4 \%$ olive cake. The birds fed the diets for 63 days. At $63^{\text {rd }}$ day, ten birds per replicates at the same body weight were slaughtered (Tougan et al., 2013). Breast muscle was collected with thigh and wing (with the same proportions) and chopped then frying was done 
in sunflower oil at $175-180^{\circ} \mathrm{C}$ for $0.5: 2 \mathrm{~min}$ to estimate the sensory evaluation test. The OS and bacteriological activity of fresh chicken meat during the storage period ( 15 days) at $4{ }^{\circ} \mathrm{C} \pm 1$ were determined.

\section{Sensory evaluation of chicken meat fed on} olive cake

Chicken fed on different rates of OC were sensory tested at zero time for their colour, odour, texture, taste and overall acceptability after frying on a 1 to 15 hedonic scale as defined by Meilgaard et al. (2007).

Quality characteristics of the chicken meat (breast, thigh and wing muscle)

Moisture, ether extract, protein and ash contents of the chicken meat were estimated using the methods outlined in AOAC (2005).

\section{Peroxide value (PV)}

Peroxide value (PV) of oil extracted from the chicken meat (breast, thigh and wing muscle) was measured using the method outlined by Leonard et al. (1987).

\section{Thiobarbituric acid reactive substances (TBARS)}

TBARS assay was made according to the method of Nirmal and Benjakul (2009) and TBA value was expressed as mg malondialdehyde (MDA)/kg chicken.

\section{Total bacterial counts (TBC)}

Total bacterial counts (TBC) of chicken meat (breast, thigh and wing muscle) were estimated by the shelf life at 0 and 15 days in plate count agar by the pour-plate method (Difco, 1977).

\section{RESULTS AND DISCUSSION}

\section{Proximate Chemical Composition of Olive Cake}

The results presented in Table 1 cleared that the chemical composition of OC and found low crude protein $(7.0 \mathrm{~g} / 100 \mathrm{~g})$ and high ether extract and crude fiber contents (12.57 and $50.87 \mathrm{~g} / 100$ g), respectively. In addition, moisture, available carbohydrates and ash contents of OC were $7.12,21.14$ and $8.42 \mathrm{~g} / 100 \mathrm{~g}$ (on dry weight basis), respectively. These results are in agreement with that mentioned by Alburquerque et al. (2004) and Alvarez-Rodríguez et al. (2009).

Alvarez-Rodríguez et al. (2009) evaluated chemical composition of OC and found a higher ether extract $(11.7 \mathrm{~g} / 100 \mathrm{~g})$. Alburquerque $\boldsymbol{e t}$ al. (2004) analyzed olive cake and found that crude protein valued $7.2 \mathrm{~g} / 100 \mathrm{~g}$ and ether extract $12.1 \mathrm{~g} / 100 \mathrm{~g}$ (on dry weight basis).

\section{Minerals Content of Olive Cake}

The results in Table 2 illustrate minerals content of olive cake. The highest value of minerals content was $\mathrm{Na}(6651.5 \mathrm{ppm})$ followed by $\mathrm{Ca}$ (3010 ppm), K (2985 ppm), Mg (2053 ppm), P (1546.5 ppm) then Fe (85.5 ppm) and Mn $(17.15 \mathrm{ppm})$ were the lowest. Due to the high organic load and substantial amounts of plant nutrients $(\mathrm{P}, \mathrm{N}, \mathrm{K}, \mathrm{Fe}$ and $\mathrm{Ca})$ in the composite $\mathrm{OC}$, it can be used as fertilizers, especially it showed a great degree of humification and no phytotoxic effect (Hachicha et al., 2006).

\section{Fatty Acids Analysis}

From the results presented in Table 3, it can be observed that, the main fatty acids of OC were the unsaturated oleic acid (18:1) (72.1\%), the linoleic (18:2) (9.5\%), the palmatic (C16:0) $(7.3 \%)$, stearic acid (14:0) (4.4\%) and linolenic acid (18:3) (4.1\%). Opposition of polyunsaturated oils (linoleic, linolenic and arachidonic) to oxidation depends on factors such as exposure to oxygen, exposure to light, the existence of pigments and heavy metals as well as saturation degree (Gutierrez et al., 2008).

Alcaide et al. (2003) reported that, the high oleic content of OC was $67.9 \mathrm{~g} / 100 \mathrm{~g}$. Although, Vargas-Bello-Pérez et al. (2013) found a higher proportion of oleic content of olive cake $(75.8 \mathrm{~g} / 100 \mathrm{~g})$. From all this, it can be inferred the importance of a high accuracy in the characterization of by-products prior to be used in the formulation of commercial feedstuffs.

\section{The sensory evaluation of chicken}

The sensory properties of chicken meat fed on diet with added olive cake $(0,2$ and $4 \%)$ are shown in Table 4. It is clear that the chicken meat with the two and four percentages had relatively near values for colour, taste, odour, texture and overall acceptability compared to control sample. There were no significant 
Table 1. Proximate chemical composition (on dry weight basis) of olive cake

\begin{tabular}{lcccccc}
\hline Component & $\begin{array}{c}\text { Moisture } \\
\mathbf{( \% )}\end{array}$ & $\begin{array}{c}\text { Crude protein } \\
\mathbf{( \% )}\end{array}$ & $\begin{array}{c}\text { Ether extract } \\
\mathbf{( \% )}\end{array}$ & $\begin{array}{c}\text { Ash } \\
\mathbf{( \% )}\end{array}$ & $\begin{array}{c}\text { Crude fiber } \\
\mathbf{( \% )}\end{array}$ & $\begin{array}{c}\text { Available } \\
\text { carbohydrates (\%) }\end{array}$ \\
\hline Olive cake & 7.12 & 7.0 & 12.57 & 8.42 & 50.87 & 21.14 \\
\hline
\end{tabular}

Table 2. Minerals content (ppm) of olive cake (on dry weight basis).

\begin{tabular}{lcccccccc}
\hline & \multicolumn{8}{c}{ Minerals (ppm) } \\
\cline { 2 - 9 } & $\mathbf{N a}$ & $\mathbf{K}$ & $\mathbf{C a}$ & $\mathbf{M g}$ & $\mathbf{C u}$ & $\mathbf{F e}$ & Mn & P \\
\hline Olive cake & 6651.5 & 2985 & 3010 & 2053 & 4.5 & 85.5 & 17.15 & 1546.4 \\
\hline
\end{tabular}

Table 3. Fatty acids analysis of olive cake

Fatty acids analysis $(\%)$

\begin{tabular}{ccccccc} 
& $\begin{array}{c}\text { Palmatic } \\
\text { acid }\end{array}$ & $\begin{array}{c}\text { Stearic } \\
\text { acid }\end{array}$ & $\begin{array}{c}\text { Oleic } \\
\text { acid }\end{array}$ & $\begin{array}{c}\text { Linoleic } \\
\text { acid }\end{array}$ & $\begin{array}{c}\text { Linolenic } \\
\text { acid }\end{array}$ & $\begin{array}{c}\text { Unknown } \\
\text { fatty acids }\end{array}$ \\
\hline Olive cake & 7.3 & 4.4 & 72.1 & 9.5 & 4.1 & 2.2 \\
\hline
\end{tabular}

Table 4. The sensory evaluation of fried chicken meat fortified by olive cake

\begin{tabular}{lccccc}
\hline Olive cake & \multicolumn{5}{c}{ Sensory properties } \\
\cline { 2 - 6 } & Colour & Taste & Texture & Odour & Overall acceptability \\
\hline Control & $8.5 \pm 0.99^{\text {a }}$ & $8.2 \pm 1.2^{\text {a }}$ & $8.8 \pm 0.83^{\text {a }}$ & $8.5 \pm 1^{\text {a }}$ & $8.5 \pm 0.96^{\text {a }}$ \\
$\mathbf{2 \%}$ & $8.3 \pm 0.98^{\text {a }}$ & $8.1 \pm 0.90^{\text {a }}$ & $8.6 \pm 0.79^{\text {a }}$ & $8.2 \pm 1.3^{\text {a }}$ & $8.3 \pm 0.98^{\text {a }}$ \\
$\mathbf{4 \%}$ & $8.2 \pm 1^{\text {ab }}$ & $8.1 \pm 1.3^{\text {a }}$ & $8.5 \pm 1.1^{\text {ab }}$ & $8.1 \pm 1.1^{\mathrm{b}}$ & $8.2 \pm 0.99^{\text {ab }}$ \\
\hline
\end{tabular}

Averages in the same row with unlike superscripts differed significantly $(\mathrm{P} \leq 0.05)$. 
differences $(\mathrm{P} \leq 0.05)$ of sensory properties among 0,2 and $4 \%$ samples. The taste is a feeling perceived by the tongue and influenced by the texture. Taste ranged from 8.2 to 8.1 , colour and overall acceptability ranged from 8.5 to 8.2 and odour ranged from 8.5 to 8.1 .

\section{Quality Characteristics of Chicken Meat (Breast, Thigh and Wing Muscle)}

Results given in Table 5 show that the olive cake percentage had affected on all quality characteristics of chicken meat. Increasing the percentage of OC in the chicken diet improved the moisture, fat, ash and protein contents. Majed et al. (2016) indicated that the biological value of diverse concentrations of $\mathrm{OC}$ as improvers of the storability, quality and safety of beef patties was studied. Increasing the percentage of OC in the patties improved the fat and protein contents, moisture, cooking yield and fat retention.

\section{The OS of Chicken Meat}

The results presented in Figs. 1 and 2 show that the addition of the olive cake in the chicken diet ( 2 and $4 \%$ ) had an effect on lipid oxidation of meat during the storage periods $(0,3,6,9,12$ and 15 days). The primary oxidation products measured by estimation of PV and the secondary oxidation products measured by estimation of TBARS. The PV of chicken meat fed on $2 \%$ OC was significantly $(\mathrm{P} \leq 0.05)$ higher than that of $4 \%$ OC at the storage period. In addition, PV values of chicken meat fed on 2 and $4 \%$ olive cake were significantly $(\mathrm{P} \leq 0.05)$ lower than that of control at the storage period. PV values of chicken meat fed on 2 and $4 \%$ olive cake were 7.6 and $6.9 \mathrm{meq} \mathrm{O}^{2} / \mathrm{kg}$ oil at the end of storage period (15 days), with compared to the control ( $8.5 \mathrm{meq} \mathrm{O} / \mathrm{kg}$ oil). PV values increased by increasing of storage period. Also, TBARS values of chicken meat fed on $4 \%$ olive cake were significantly $(\mathrm{P} \leq 0.05)$ lower than that of $2 \%$ olive cake at the storage period. In addition, TBARS values of chicken meat fed on $2 \%$ olive cake was significantly lower than that of chicken meat without olive cake (control) at the storage period. TBARS values of chicken meat fed on 0 , 2 and $4 \%$ olive cake were $3.11,2.84$ and 2.66 $\mathrm{mg} \mathrm{MDA} / \mathrm{kg}$ at the storage period.

Using of $4 \%$ olive cake was better than $2 \%$ in chicken diets for reducing lipid oxidation because olive cake contain on minerals and phenolic compounds of $2 \%$ OC less than $4 \%$ OC. However, olive cake contain on high percentage of unsaturated fatty acids $(85.7 \%)$. Also, The performance of poultry and is advisedly affected by the presence of dietary NSP (Gil-Serrano and Tejero-Mateo, 1988; Saleh et al., 2015).

The OS of unsaturated fatty acids reduces with increasing unsaturation degree due to unsaturated sites are the most susceptible sites for heat induced and radical-based fat oxidation. The products made are like those of autooxidation but the amounts formed vary with temperature even within low temperature ranges of $25-80^{\circ} \mathrm{C}$ (Stewart et al., 2003).

Polyphenol limits the initiation of lipid oxidation by binding metals, such as $\mathrm{Fe}$ and $\mathrm{Cu}$, stabilizing them in an inactive form. Meat colour can thus be conserved because of the antioxidants ability to limit oxidation, inhibiting of reactive aldehydes and preventing ironcatalysed lipid oxidation (Allen and Cornforth, 2010; Dal Bosco et al., 2012).

\section{Bacteriological Determination}

The results presented in Table 6 show that the distribution of total bacteria in chicken meat fed on different rates of olive cake. The total bacteria of chicken fed on $2 \%$ olive cake was found $1.2 \times 10^{2}$ and $3.9 \times 10^{3} \mathrm{cfug}^{-1}$ at 0 and 15 days, respectively. While, the total bacteria of chicken fed on $4 \%$ olive cake was found $1.1 \times$ $10^{2}$ and $2.5 \times 10^{3}$ cfug $^{-1}$ at 0 and 15 days, respectively. The total bacteria of control were $1.4 \times 10^{2}$ and $6.1 \times 10^{4} \mathrm{cfug}^{-1}$ at 0 and 15 days, respectively. These values are close to the counts reported by Kilonzo-Nthenge $\boldsymbol{e t} \boldsymbol{a l}$. (2013), total bacteria numbers were between 3.26 (chicken wings) and $4.75 \mathrm{cfug}^{-1}$ (chicken breast).

\section{Conclusion}

This study confirms the importance of olive cake as a vital source of oil especially total monounsaturated fatty acids, crude fiber and minerals. In addition, olive cake as by-product improved the shelf life and dietary value of chicken meat through the storage period. Therefore, adding olive cake in a concentratebased diet for chicken could be recommended as a natural plan to improve the nutritional quality of chicken without compromising its oxidative stability. 
Table 5. Effect of olive cake on quality characteristics of chicken meat

\begin{tabular}{lcccc}
\hline Olive cake & \multicolumn{4}{c}{ Quality characteristics } \\
\cline { 2 - 5 } & Moisture (\%) & Total ash (\%) & Fat (\%) & Protein (\%) \\
\hline Control & 72.4 & 0.87 & 1.80 & 19.23 \\
$\mathbf{2 \%}$ & 72.5 & 0.89 & 1.86 & 20.49 \\
$\mathbf{4 \%}$ & 72.5 & 0.90 & 1.95 & 20.63 \\
\hline
\end{tabular}

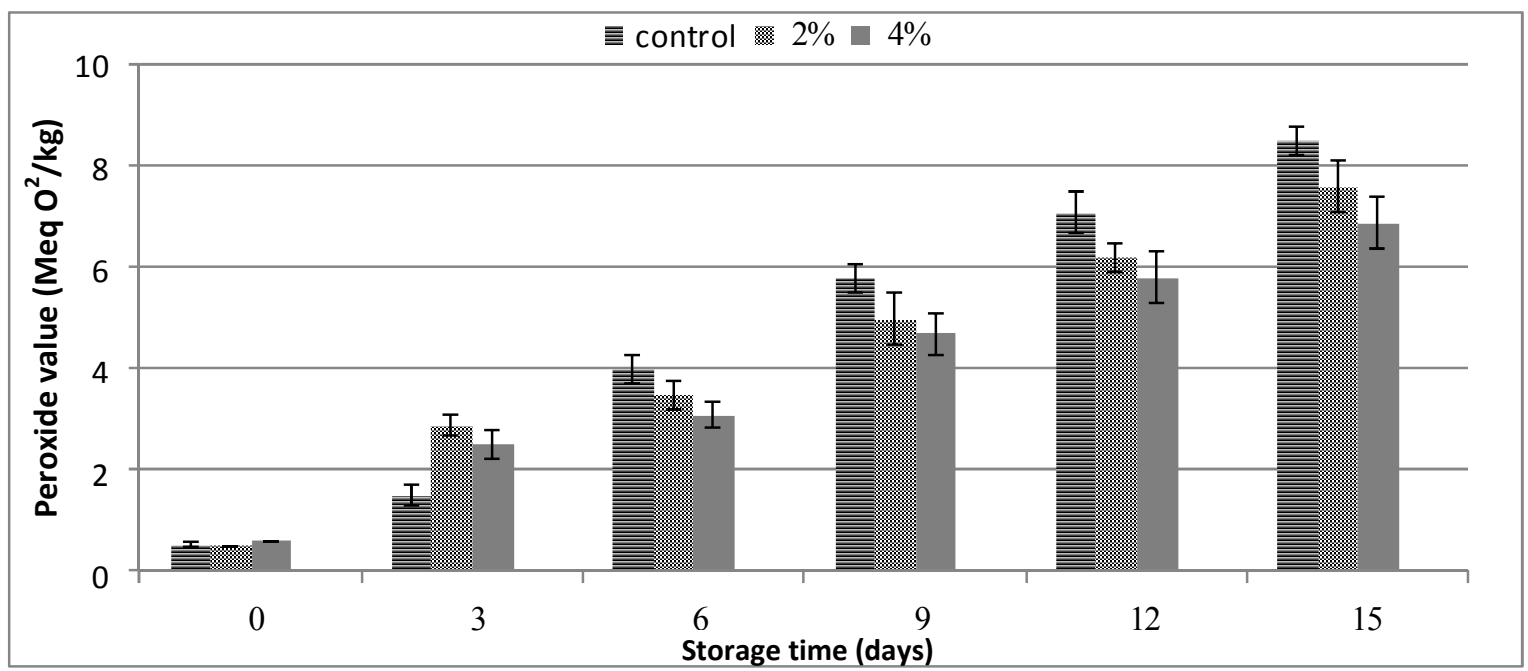

Fig. 1. The effect of storage time on peroxide value (meq $\mathrm{O}^{2} / \mathrm{kg}$ oil) of chicken meat fed on diet with added olive cake compared with control at $4 \pm 1^{\circ} \mathrm{C}$

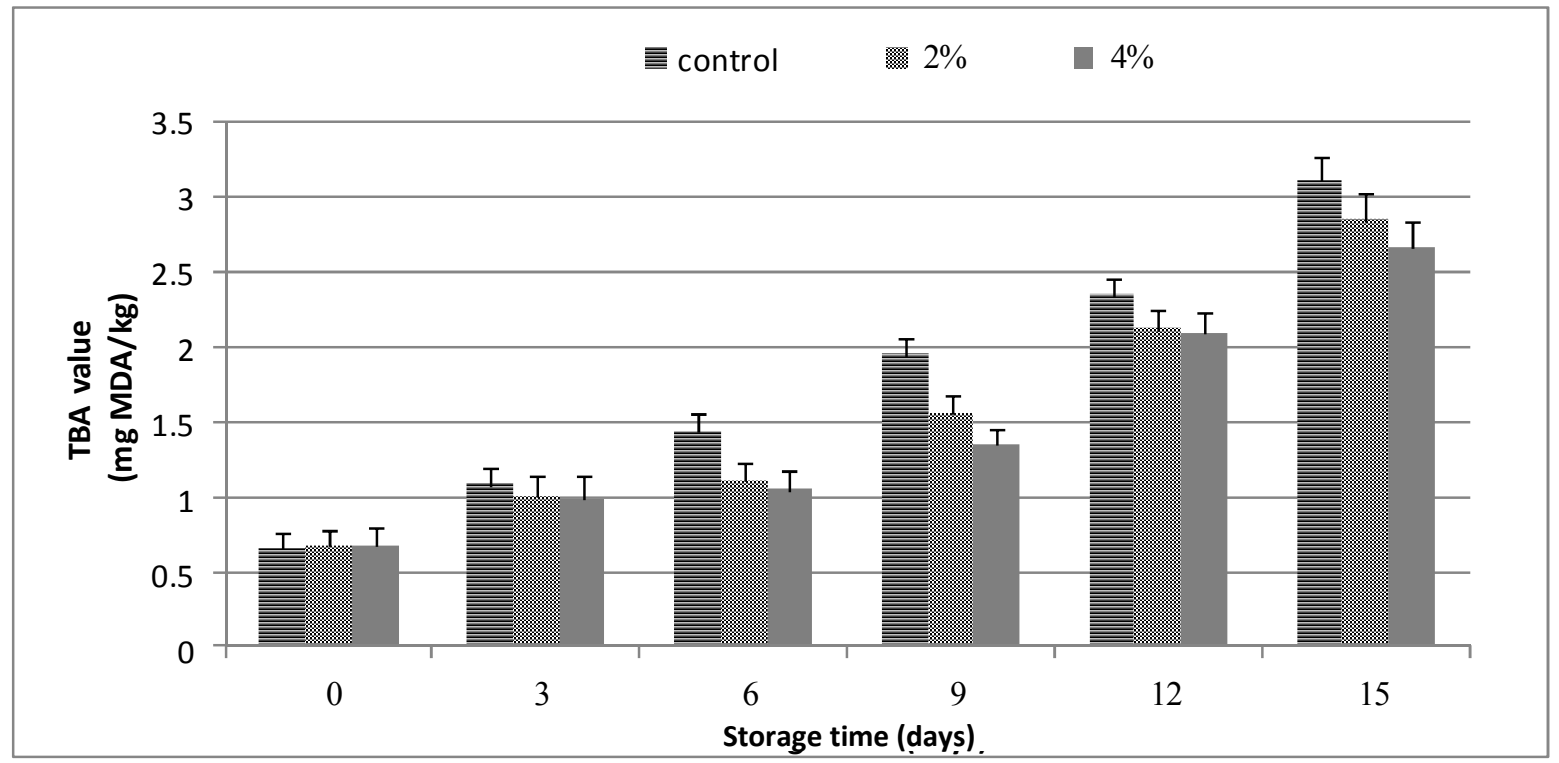

Fig. 2. The effect of storage time on thiobarbituric reactive substances (mg MDA $/ \mathrm{kg})$ of chicken meat fed on diet with added olive cake compared with control at $4 \pm 1^{\circ} \mathrm{C}$ 
Table 6. Total bacterial counts $\left(\mathrm{cfug}^{-1}\right)$ of chicken meat fed on olive cake during the storage periods at $4^{\circ} \mathrm{C} \pm 1$

\begin{tabular}{lcc}
\hline Olive cake & \multicolumn{2}{c}{ Storage period (day) } \\
\cline { 2 - 3 } & $\mathbf{0}$ & $\mathbf{1 5}$ \\
\hline Control & $1.4 \times 10^{2}$ & $5.1 \times 10^{4}$ \\
$\mathbf{2 \%}$ & $1.2 \times 10^{2}$ & $3.9 \times 10^{3}$ \\
$\mathbf{4 \%}$ & $1.1 \times 10^{2}$ & $2.5 \times 10^{3}$ \\
\hline
\end{tabular}

\section{REFERENCES}

Abo-Omar, J. (2000). Effect of different levels of olive pulp on the digestibility of broiler chicks. J. Bethlehem Univ., 12:34-40.

Abo-Omar, J. (2005). Carcass composition and visceral organ mass of broiler chicks fed different levels of olive pulp. J. Islamic Univ. Gaza., 13:75-84.

Alcaide, E.M., D.Y. Ruiz, A. Moumen and I.M. Garcia (2003). Chemical composition and nitrogen availability for goats and sheep of some olive by-products. Small Rumin. Res., 49: 329-336.

Alburquerque, J.A., J. Gonzalez, D. García and J. Cegarra (2004). Agrochemical characterisation of alperujo, a solid byproduct of the two-phase centrifugation methods for olive oil extraction. Bioresour. Technol., 91:195-200.

Alhusein, M.A., O. Abu-Leiyah and G.A. Inayatullah (1993). Combined system of renewable energy for grid-connected advanced communities. Renewal Energy, 3 (7): 557-569.

Allen, K. and D. Cornforth (2010). Comparison of spice-derived antioxidants and metal chelators on fresh beef colour stability. Meat Sci., 85 : 613-619.

Alvarez-Rodríguez, J., F. Munoz and M. Joy (2009). Nutritive value of crude and extracted two-stage olive cakes produced in Aragón (Spain). Rev. Electron. Vet., $10: 1-8$.

AOAC (2005). Association of Official Analytical Chemists. Official Methods of Analysis.; $18^{\text {th }}$ Ed. Washington, DC., USA.
Chapman, H.D. and P.F. Pratt (1978). Methods of Analysis for Soil, Plants and Waters. Calif. Univ., Division of Agric. Sci. Priced Publication, 4034 : 50.

Dal Bosco, A., E. Mourvaki, R. Cardinali, M. Servili, B. Sebastiani, S. Ruggeri, S. Mattioli, A. Taticchi, S. Esposto and C. Castellini (2012). Effect of dietary supplementation with olive pomaces on the performance and meat quality of growing rabbits. Meat Sci., 92: 783-788.

Descalzo, A.M. and A.M. Sancho (2008). A review of natural antioxidants and their effects on oxidative status, odour and quality of fresh beef produced in Argentina. Meat Sci., 79:423-436.

Difco, M. (1977). Dehydrated Culture Media and Reagents for Microbiological and Clinical Laboratory Procedures. $9^{\text {th }}$ Ed., Detroit, Michgan, USA.

Faustman, C., Q. Sun, R. Mancini and S.P. Suman (2010). Myoglobin and lipid oxidation interactions: Mechanistic bases and control. Meat Sci., 86: 86-94.

Folch, J., M. Lees and G.H. Sloane-Stanley (1957). A simple method for the isolation and purification of total lipids from animal tissues. J. Biol. Chem., 226:497-509.

Gil-Serrano, A. and P. Tejero-Mateo (1988). A xyloglucan from olive pulp. Carbohydr. Res., $181: 278-281$.

Gutierrez, L., C. Ratti and K. Belkacemi (2008). Effects of drying method on the extraction yields and quality of oils from quebec sea buckthorn (Hippophae rhamnoides L.) seeds and pulp. Food Chem., 106: 896-904. 
Hachicha, S., M. Chtourou, E. Medhioub and K. Ammar (2006). Compost of poultry manure and olive mill waste as alternative fertilizer. Agron. Sustain. Dev., 26: 135-142.

Hur, S.J., G.B. Park and S.T. Joo (2007). Formation of cholesterol oxidation products (COPs) in animal products. Food Control, 18: 939-947.

Kilonzo-Nthenge, A., E. Rotich and S.N. Nahashon (2013). Evaluation of drugresistant Enterobacteriaceae in retail poultry and beef. Poult. Sci., 92 (4): 1098-1107.

Leonard, W.A., A.E. Woods and M.K. Wells (1987). Food Composition and Analysis. Published by van nostrand Reinhold Company, New York., USA.

Majed, D.H., A. Fahad, A.M.A. Isam, G. Kashif and E.B. Elfadil (2016). Physicochemical, microbiological and sensory evaluation of beef patties incorporated with destined olive cake powder. J. Meat Sci., 122:32-39.

Martín-García, A.I., A. Moumen, D.R. YanezRuiz and E.M. Alcaide (2003). Chemical composition and nutrients availability for goats and sheep of two-stage olive cake and olive leaves. Anim. Feed Sci. Technol., 107: 61-74.

Meilgaard, M.C., G.V. Civileand and B.T. Carr (2007). Sensory Evaluation Techniques. $4^{\text {th }}$ Ed. CRC Press: New York.

Molina-Alcaide, E. and D.R. Yáñez Ruiz (2008). Potential use of olive by-products in ruminant feeding: A review. Animal Feed Sci. Technol., 147: 247-264.

Nirmal, N.P. and S. Benjakul (2009). Effect of ferulic acid on inhibition of polyphenoloxidase and quality changes of Pacific white shrimp (Litopenaeus vannamei) during iced storage. J. Food Chem., 116:323-331.

Rupic, V., V. Bozikov, R. Bozac, S. Muzic, N. Varnesic and M. Dikic (1999). Effect of feeding olive by-products on certain blood parameters and serum enzyme activities of fattening rab- bits. Acta Vet Hung, 47:65-75.

Saleh, A.A., H. Kunioki, I. Daichi and O. Akira (2015). The influence of dietary supplementation with Aspergillus awamori and feeding canola seeds on the growth performance and meat quality in male broilers chickens. J. Anim. Sci., 86 (3): 305311.

Servili, M., S. Esposto, R. Fabiani, S. Urbani, A. Taticchi, F. Mariucci, R. Selvaggini and G.F. Montedoro (2009). Phenolic compounds in olive oil: antioxidant, health and organoleptic activities according to their chemical structure. Inflammopharmacol., 17:1-9.

Stewart, O.J., G. Raghavan, V. Orsat and K.D. Golden (2003). The effect of drying on unsaturated fatty acids and trypsin inhibitor activity in soybean. Process Biochem., 39: 483-489.

Sukhija, P.S. and D.L. Palmquist (1988). Rapid method for determination of total fatty acid content and composition of feedstuffs and feces. J. Agric. Food Chem., 36: 1202-1206.

Tougan, P.U., A.K.I. Youssao, M. Dahouda, C.F.A. Salifou; G.S. Ahounou, M. Kopdekon, G.A. Mensah, D.N. Kossou, C. Amenou, C. Kogbeto and A. Thewis (2013). Variability of carcass traits of local poultry populations of Gallus gallus spices of Benin by genetic type, breeding mode and slaughter age. Inter. J. Poult. Sci., 12 (8): 473-483.

Vargas-Bello-Pérez, E., R.R. Vera, C. Aguilar, R. Lira, I. Pena, A. Valenzuela and H. Cerda (2013). Effect of dietary inclusion of lampante olive oil in milk and cheese fatty acid profiles of ewes. Grasas Aceites, 54: 295- 303.

Zanardi, E., E. Novelli, N. Nanni, P. Ghiretti, G. Delbono, G. Campanini, G. Dazzi, G. Madarena and R. Chizzolini (1998). Oxidative stability and dietary treatment with vitamin E, oleic acid and copper of fresh and cooked pork chop. Meat Sci., 42:309-320.

Zangeneh, S. and M. Torki (2011). Effects of $\beta$ Mannanase supple menting of olive pulp included diet on performance of laying hens, egg quality characteristics, humoral and cellular immune response and blood parameters. Global Vet., 7:391-398. 


\title{
استخام مخلف تفل الزيتون فى تحسين العمر التخزينى وجودة لحوم الدجاج
}

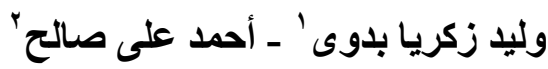

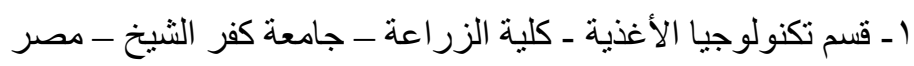

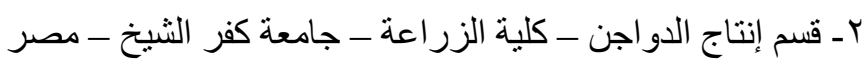

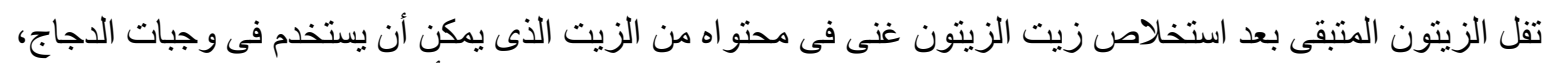

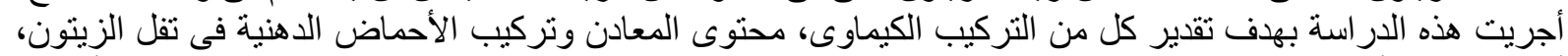

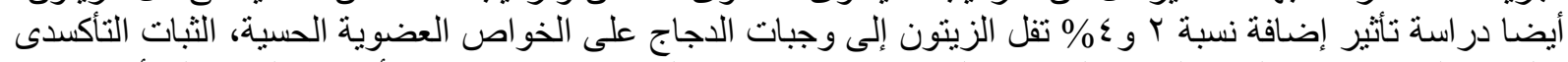

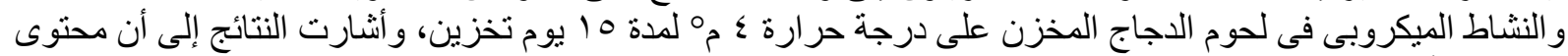

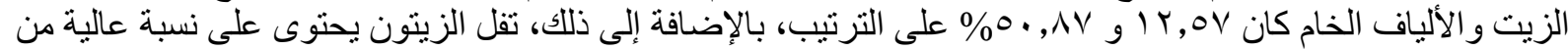

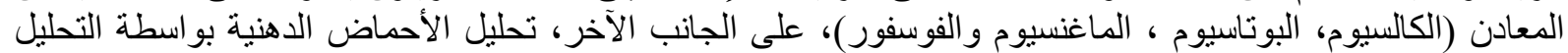

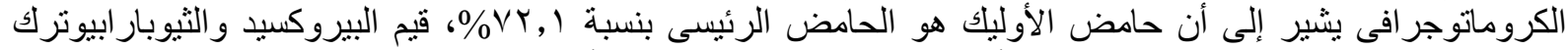

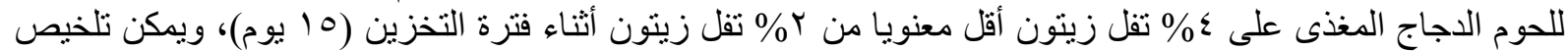

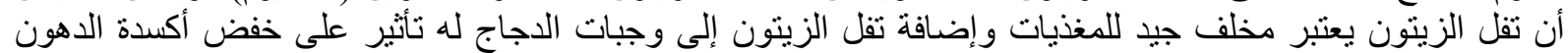

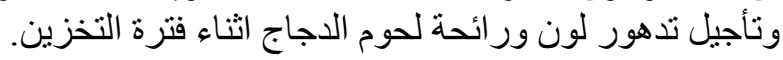

